\title{
Detection of erythroid hypoplasia in myelofibrosis using erythrokinetic studies
}

\author{
J E HOWARTH, H M WATERS, K HYDE, C G GEARY \\ From the University Department of Clinical Haematology, Manchester Royal Infirmary, Manchester
}

SUMMARY The iron kinetic model described by Ricketts et al was used to study haemopoiesis in chronic myelofibrosis. The clearance of ${ }^{59} \mathrm{Fe}$-labelled transferrin from the plasma was analysed to quantify total, effective, and ineffective erythropoiesis, denoted by the terms marrow iron turnover (MIT), red cell iron turnover (RCIT), and per cent ineffective iron turnover (IIT\%), respectively, in 12 cases of this disease. The patterns obtained were variable: values for MIT ranged from 24.4 to 510 $\mu \mathrm{mol} / 1 \mathrm{blood} / \mathrm{day}$; those for RCIT from 0.4 to $119 \mu \mathrm{mol} / 1 \mathrm{blood} / \mathrm{day}$; and those for IIT\% from 67 to $98 \%$. One noteworthy feature was the presence in two cases of functional erythroid hypoplasia; these were characterised by severely reduced values for MIT ( 24.4 and $28 \mu \mathrm{mol} / \mathrm{l} \mathrm{blood} / \mathrm{day})$ and RCIT ( 0.4 and $8 \mu \mathrm{mol} / 1$ blood/day.)

A systematic study of the erythrokinetic features of myelofibrosis may indicate that erythroid hypoplasia is a more common cause of anaemia in this disease than has been previously recognised.

Several different factors influence the severity of anaemia in myelofibrosis: among these are bone marrow failure, haematinic deficiency, blood loss, an enlarged spleen with red cell sequestration and haemolysis, plasma volume expansion, and haemoconcentration in an enlarged spleen. The erythrokinetic patterns observed in different cases and at different stages reflect these variables.

\section{Patients and methods}

Ferrokinetic measurements were carried out on 12 patients with myelofibrosis.' All had increased concentrations of reticulin in the bone marrow; they also had enlarged spleens and blood pictures showing varying degrees of anisocytosis and poikilocytosis. Haematological data for the patients is shown in table 1. Cases 1, 2 and 3 had previously been diagnosed as having polycythaemia vera and were venesected as required, but not within 10 days before or during the ferrokinetic study. Case 4 had received busulphan during the earlier course of his disease, but no cytotoxic drugs were administered immediately before or during the ferrokinetic study. Several patients had received folic acid. Cases 7, 9, 11 and 12 were transfused as required, excluding the period 10 days

Accepted for publication 31 August 1989 before or during the course of the ferrokinetic study. Case 12 had received calcitriol on previous occasions but with no apparent haematological benefit. None of the other patients received drugs during the period of study.

Transferrin bound ${ }^{59} \mathrm{Fe}$ was prepared ${ }^{2}$ and $4 \mathrm{ml}$ plasma, containing between $0.2 \mathrm{MBq}$ and $0.4 \mathrm{MBq}$ of label, was injected intravenously. Venous blood samples were collected at timed intervals over 10-14 days. All plasma samples were deproteinised to remove ${ }^{59} \mathrm{Fe}$ haemoglobin before counting and curve fitting. ${ }^{3}$

Plasma iron turnover (PIT), marrow iron turnover (MIT), red cell iron turnover (RCIT), percentage ineffective iron turnover (IIT\%) and mean red cell lifespan (MRCL) were determined. Red cell volume (RCV) and plasma volume (PV) were measured by a dilution of ${ }^{51} \mathrm{Cr}$ labelled red cells ${ }^{4}$ and ${ }^{59} \mathrm{Fe}$ labelled transferrin, ${ }^{5}$ respectively. Surface counting was performed over the spleen, liver, sacrum and precordium to identify sites of red cell production and destruction in 10 of the patients. ${ }^{6}$ Venous blood samples were stained for reticulocytes using a modification of the method of Dacie and Lewis. ${ }^{6}$ A 50:50 mixture of whole blood and $0.5 \%$ new methylene blue was prepared. After a staining period of seven minutes at room temperature a reticulocyte smear was prepared and counted using a microscope fitted with a graticule in one eyepiece. The reference values shown in table 1 are those routinely reported for clinical purposes. 
Table 1 Haematological data

\begin{tabular}{|c|c|c|c|c|c|c|}
\hline Case No & Sex & $\begin{array}{l}\text { Haemoglobin } \\
(g / d l)\end{array}$ & $\begin{array}{l}\text { Reticulocytes } \\
(\%)\end{array}$ & $\begin{array}{l}\text { Reticulocytes } \\
\left(10^{9} / 1\right)\end{array}$ & $\begin{array}{l}\text { Red cell volume } \\
(\mathrm{ml} / \mathrm{kg} \text { body weight })\end{array}$ & $\begin{array}{l}\text { Plasma volume } \\
\text { ( } \mathrm{ml} / \mathrm{kg} \text { body weight) }\end{array}$ \\
\hline $\begin{array}{l}1 \\
2 \\
3 \\
4 \\
5 \\
6 \\
7 \dagger \\
8 \\
9 \dagger \\
10 \\
11 \dagger \\
12 \dagger\end{array}$ & $\begin{array}{l}\mathbf{F} \\
\mathbf{M} \\
\mathbf{F} \\
\mathbf{M} \\
\mathbf{F} \\
\mathbf{M} \\
\mathbf{F} \\
\mathbf{M} \\
\mathbf{M} \\
\mathbf{M} \\
\mathbf{F} \\
\mathbf{F}\end{array}$ & $\begin{array}{l}16 \\
14 \cdot 6 \\
14 \cdot 4 \\
12 \cdot 8 \\
11 \cdot 5 \\
10 \cdot 2 \\
6 \cdot 8 \\
7 \cdot 6 \\
9 \cdot 5 \\
8 \cdot 8 \\
6 \\
3\end{array}$ & $\begin{array}{c}3 \\
2.6 \\
<1 \\
2.9 \\
4.8 \\
5.9 \\
- \\
- \\
- \\
- \\
<1.5 \\
<1\end{array}$ & $\begin{array}{r}183 \\
150 \\
<100 \\
148 \\
196 \\
234 \\
- \\
- \\
<100 \\
- \\
<100 \\
<100\end{array}$ & $\begin{array}{l}40 \cdot 1 \\
41 \cdot 2 \\
40 \\
32 \cdot 1 \\
21 \\
18 \cdot 3 \\
17 \cdot 1 \\
22 \cdot 7 \\
17 \cdot 9 \\
18 \cdot 5 \\
18 \cdot 2 \\
20\end{array}$ & $\begin{array}{l}46 \cdot 8 \\
72 \cdot 8 \\
51 \\
63 \\
57 \cdot 8 \\
54 \cdot 9 \\
67 \cdot 3 \\
103 \\
59 \cdot 5 \\
73 \cdot 9 \\
61 \cdot 1 \\
62 \cdot 9\end{array}$ \\
\hline
\end{tabular}

†Transfused prior to study

Reference ranges

Haemoglobin Men 13-18 g/dl Women $11.5-16.5 \mathrm{~g} / \mathrm{dl}$

Reference values

Reticulocytes $(\%)<1$

Reticulocytes $\left(10^{9} / 1\right)<100$

\section{Results}

Haematological data indicated a wide variation in haemoglobin concentration and reticulocyte count at presentation (table 1). For six patients (cases 1-6), the haemoglobin concentration was either normal or slightly reduced. With the exception of case 3 , the reticulocyte count was raised. For the remaining patients, the haemoglobin concentration was moderately or severely reduced. Reticulocyte counts for cases 9,11 and 12 suggested an apparent lack of marrow response to the anaemia. Erythrokinetic data also illustrated the heterogeneity of myelofibrosis (table 2). Ten of the patients (1-10) were characterised by a normal or increased MIT. A normal RCIT was obtained for eight patients, while the remaining two (cases 9 and 10) showed a definite reduction.

Cases 11 and 12 differed considerably from the
Red cell volume Men $\quad 25-35 \mathrm{ml} / \mathrm{kg}$ body weight Women $20-30 \mathrm{ml} / \mathrm{kg}$ body weight

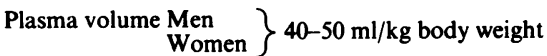

above. Both had normal values for PIT but showed reduced MIT and RCIT. The surface counting pattern also clearly differentiated these patients from the others. These patients showed exclusive uptake of ${ }^{59} \mathrm{Fe}$ by the liver with no detectable release into the circulation during the period of study, indicating storage of the label rather than utilisation for erythropoiesis. The other patients showed uptake of ${ }^{59} \mathrm{Fe}$ by both spleen and sacrum, or by spleen alone, with subsequent release into the circulation, suggesting use of the iron for erythropoiesis rather than storage.

\section{Discussion}

Our erythrokinetic studies have shown the heterogeneous nature of myelofibrosis (also reflected in the clinical course) and the haematological and histological features of this syndrome. Half of the patients

Table 2 Erythrokinetic data

\begin{tabular}{|c|c|c|c|c|c|c|c|c|c|c|}
\hline \multirow[b]{2}{*}{ Case No } & \multirow[b]{2}{*}{ Sex } & $P I T$ & $M I T$ & $R C I T$ & \multirow{2}{*}{$\begin{array}{l}I I T \\
(\%)\end{array}$} & \multirow{2}{*}{$\begin{array}{l}M R C L \\
\text { (days) }\end{array}$} & Spleen & Liver & \multirow[t]{2}{*}{ Sacrum } & \\
\hline & & \multicolumn{3}{|c|}{ ( $\mu \mathrm{mol} / \mathrm{l}$ blood/day) } & & & \multicolumn{2}{|c|}{$\left(\%\right.$ uptake of $\left.{ }^{59} \mathrm{Fe}\right)$} & & \\
\hline $\begin{array}{c}1 \\
2 \\
3 \\
4 \\
5 \\
6 \\
7 \dagger \\
8 \\
9 \dagger \\
10 \\
11 \dagger \\
12 \dagger\end{array}$ & $\begin{array}{l}\mathbf{F} \\
\mathbf{M} \\
\mathbf{F} \\
\mathbf{M} \\
\mathbf{F} \\
\mathbf{M} \\
\mathbf{F} \\
\mathbf{M} \\
\mathbf{M} \\
\mathbf{M} \\
\mathbf{F} \\
\mathbf{F}\end{array}$ & $\begin{array}{l}390 \\
199 \\
242 \\
318 \\
550 \\
283 \\
512 \\
213 \\
181 \\
549 \\
155 \\
132\end{array}$ & $\begin{array}{l}388 \\
196 \\
141 \\
310 \\
367 \\
195 \\
510 \\
208 \\
173 \\
412 \\
28 \\
24 \cdot 4\end{array}$ & $\begin{array}{c}119 \\
56 \\
47 \\
66 \\
65 \\
55 \\
51 \\
47 \\
28 \\
27 \\
8 \\
0.4\end{array}$ & $\begin{array}{l}69 \\
71 \\
67 \\
79 \\
82 \\
72 \\
90 \\
77 \\
84 \\
93 \\
71 \\
98\end{array}$ & $\begin{array}{r}78 \\
130 \\
130 \\
106 \\
78 \\
93 \\
-74 \\
- \\
150 \\
-\end{array}$ & $\begin{array}{l}+ \\
* \\
++ \\
++ \\
+ \\
++ \\
+++ \\
++ \\
+ \\
+ \\
0 \\
0\end{array}$ & $\begin{array}{l}0 \\
* \\
0 \\
0 \\
0 \\
0 \\
0 \\
0 \\
* \\
+ \\
+++ \\
+++\end{array}$ & $\begin{array}{l}+ \\
+ \\
+ \\
+ \\
0 \\
0 \\
0 \\
+ \\
+ \\
+ \\
0 \\
0\end{array}$ & $\therefore$ \\
\hline
\end{tabular}

†Transfused prior to study ${ }^{*}$ Results not available

Reference ranges:

Plasma iron turnover (PIT)

Marrow iron turnover (MIT)

Red cell iron turnover (RCIT)

Ineffective iron turnover (IIT\%)

Mean red cell lifespan (MRCL)
89-183 $\mu \mathrm{mol} / 1 \mathrm{blood} /$ day

73-159 $\mu \mathrm{mol} / \mathrm{l} \mathrm{blood} / \mathrm{day}$

$54-105 \mu \mathrm{mol} / 1 \mathrm{blood} / \mathrm{day}$

$13-34 \%$

82-150 days
${ }^{59} \mathrm{Fe}$ uptake

$0=$ No detectable uptake

$+=100-130 \%$ of initial value

$++=130-180 \%$ of initial value

$+++=>180 \%$ of initial value 
examined were only slightly anaemic at presentation. Three members of this group had red cell volumes consistent with polycythaemia, although in two the effect was masked by a concomitant increase in plasma volume and would fit the label "transitional myeloproliferative disorder" identified by Pettit et al. Of the more severely anaemic group, two patients (cases 11 and 12) were remarkable in that the values for total (MIT) and effective (RCIT) erythropoiesis were indicative of erythroid depression. Despite recognising the limitations associated with surface counting procedures, ${ }^{89}$ the ${ }^{59} \mathrm{Fe}$ distribution patterns obtained for these patients were strikingly different from those of the other patients studied and suggested the possibility of erythroid hypoplasia. This was later confirmed by histological analysis when a satisfactory sample of bone marrow had been obtained.

Several investigators have produced functional classifications of myelofibrosis. Bentley et al described four patients, from a total of 62 , who showed a prolonged plasma iron half clearance time, a significant reduction in red cell utilisation, and absence of extramedullary erythropoiesis, with uptake of ${ }^{59} \mathrm{Fe}$ by the liver alone. ${ }^{10}$ Barosi et al identified three erythrokinetic classes distinguished on the basis of the association between total erythroid iron turnover, percentage ineffective iron turnover, red cell volume and degree of peripheral haemolysis. " Further work resulted in the elaboration of a prognostic classification for myelofibrosis. ${ }^{12}$ Njoku et al proposed a classification based on the association between the haemoglobin concentration and reticulocyte count at diagnosis. ${ }^{13}$ This work described four erythrokinetic classes with prognostic value.

Application of the mathematical model of Ricketts et al ${ }^{1}$ allowed us to quantify the erythropoietic state of patients with myelofibrosis and to identify the presence of concomitant erythroid hypoplasia. Cases 11 and 12 displayed similar characteristics to those described by Bentley et $a l,{ }^{10}$ and those defined as erythrokinetic class 3 by Barosi et al." Similarly, the haemoglobin:reticulocyte relation obtained at diagnosis would allocate these patients to prognostic class 4 as defined by Njoku et al, ${ }^{13}$ with a predicted mean survival of only 1.3 years. Barosi et al also found a correlation between their erythrokinetic class 3 and a poor prognosis (median survival = one year). ${ }^{11}$ Nevertheless, at the time of writing our two patients had already survived two and a half and five years, respectively. Both patients continue to require blood transfusion at regular intervals but their blood and clinical pictures have shown little change during this period, apart from some increase in spleen size. This would suggest that some patients with red cell aplasia complicating myelofibrosis may follow a more stable course resulting in variable transformation times.
Red cell aplasia has also been reported to complicate Philadelphia chromosome positive chronic granulocytic leukaemia ${ }^{14}$ and also occurs in the myelodysplastic syndrome. ${ }^{15}$ In the context of myelofibrosis, it presumably reflects an unusual phenotypic result of disordered stem cell maturation, and so far there have been no convincing reports of remission of this complication.

Myelofibrosis is a complex disorder in which the prognostic variability emphasises its heterogeneity. A systematic approach to the functional aspects of the condition will aid its characterisation and identify aspects of the syndrome which may not be readily appreciated from morphological analysis alone.

\section{References}

1 Ricketts C, Jacobs A, Cavill I. Ferrokinetics and erythropoiesis in man: the measurement of effective erythropoiesis, ineffective erythropoiesis and red cell lifespan using $59 \mathrm{Fe}$. Br J Haematol 1975;31:65-75.

2 Cavill I. The preparation of ${ }^{59} \mathrm{Fe}$-labelled transferrin for ferrokinetic studies. J Clin Pathol 1971;24:472-4.

3 Cavill I, Ricketts C, Napier JAF, Jacobs A, Trevett D, Bishop RD. The measurement of ${ }^{59} \mathrm{Fe}$ clearance from the plasma. Scand $J$ Haematol 1976;17:160-6.

4 International Committee for Standardisation in Haematology. Standard techniques for the measurement of red cell and plasma volume. Br J Haematol 1973;25:801-14.

5 Cavill I. Plasma clearance studies. In: Lewis SM, Bayly RJ, eds. Radionuclides in haematology. Edinburgh: Churchill Living= stone, 1986:214-44.

6 Dacie JV, Lewis SM. Practical haematology. Edinburgh: Churchille를 Livingstone, 1984.

7 Pettit JE, Lewis SM, Nicholas AW. Transitional myeloproliferative disorder. Br J Haematol 1979;43:167-84.

8 Milner GR, Geary CG, Wadsworth LD, Doss A. Erythrokinetic studies as a guide to the value of splenectomy in primary myeloid metaplasia. Br J Haematol 1973;25:476-84.

9 Barosi G, Baraldi A, Berzuini A, et al. The influence of regional haematocrit on in-vivo ferrokinetic measurements. Haematologica 1984;69:410-20.

10 Bentley SA, Murray KH, Lewis SM, Roberts PD. Erythroid hypoplasia in myelofibrosis: a feature associated with blastic transformation. Br J Haematol 1977;36:41-7.

11 Barosi G, Cazzola M, Frassoni F, Orlandi E, Stefanelli M. Erythropoiesis in myelofibrosis with myeloid metaplasia: recog nition of different classes of patients by erythrokinetics. $\mathrm{Br} J$ Haematol 1981;48:263-72.

12 Barosi G, Berzuini C, Liberato LN, Costa A, Polino G, Ascari E A prognostic classification of myelofibrosis with myeloid metaplasia. Br J Haematol 1988;70:397-401.

13 Njoku OS, Lewis SM, Catovsky D, Gordon-Smith EC. Anaemia in myelofibrosis: its value in prognosis. $\mathrm{Br} J$ Haematol 1983; 54:78-89.

14 Dessypris EN, McKee CL, Metzantonakis C, Teliacos M, Krantz SB. Red cell aplasia and chronic granulocytic leukaemia. $\mathrm{Br} J$ Haematol 1981;48:217-25.

15 Craig A, Geary CG, Love EM, Liu-Yin J. Red cell hypoplasia, thrombocytosis, and leucocytosis: myelodysplastic and proliferative syndrome. J Clin Pathol 1988;41:1168-70.

Requests for reprints to: Dr C G Geary, Department of Clinical Haematology, The Royal Infirmary, Manchester M13 9WL, England. 